\title{
Resource Endowment Evaluation of Sports Tourism Industry in Nine Provinces of the Yellow River Basin
}

\author{
Yuzhen Wang, Huang Yan* \\ Institute of physical education and health, research center for physical education reform and development, College \\ of physical education, Henan University, Kaifeng 475001, Henan, China \\ *Corresponding Author.
}

\begin{abstract}
Based on the methods of mathematical statistics and qualitative description analysis, this paper quantitatively evaluates and analyzes the resources endowment of sports tourism industry of nine provinces in the Yellow River Basin. Results: the regional differentiation is the prominent feature of the sports tourism resources endowment in the nine provinces of the Yellow River Basin, showing a spatial distribution pattern of rich in the southeast, poor in the northwest and moderate in the north central. Suggestions: according to the resources differences of sports tourism industry in nine provinces and autonomous regions of the Yellow River Basin, accurately positioning the development scale of sports tourism resources, deeply innovating the product system of sports tourism industry, and scientifically deciding the integration path of sports tourism resources; designing, planning, developing and publicizing sports tourism resources in a targeted way, so as to continuously improve the benefits of sports tourism resources in the Yellow River Basin and effectively promote the coordinated development of sports tourism industry in nine provinces of the Yellow River Basin.
\end{abstract}

Keywords: the Yellow River Basin, sports tourism industry, resources endowment, evaluation

\section{Introduction}

As a new way of leisure, sports tourism has become a new consumption hot spot for residents. Tourism projects characterized by sports events viewing, sports experience and outdoor leisure are more and more respected by consumers, and the trend of integration and development of sports industry and tourism industry is more and more obvious [1]. According to the data of the World Tourism Organization (UNWTO), the global sports tourism industry is growing at an annual rate of $14 \%$, exceeding the overall growth rate of $4 \%-5 \%$ of the tourism industry [2]. The Yellow River Basin is the birthplace of Chinese civilization, with magnificent and diverse landscape, profound cultural and historical accumulation, rich and unique cultural landscape. The evaluation of the endowment of sports tourism resources in the nine provinces of the Yellow River basin can objectively present the types, quantity and scale of sports tourism resources in the basin, and clarify the spatial agglomeration, resource density and structural characteristics of sports tourism resources in the basin. According to the type, quantity, quality and distribution of sports tourism resources in the region, it is of great significance for the government to formulate the spatial distribution policy of sports tourism in line with the development needs, realize the optimal allocation of sports tourism resources in the nine provinces of the Yellow River Basin, and promote the coordinated development of sports tourism industry in the Yellow River Basin.

\section{Research area and methods}

\subsection{Overview of the Yellow River Basin}

The Yellow River Basin flows through nine provinces, including Qinghai, Sichuan and Shandong etc, with a total

ISSN: 0010-8189

(c) CONVERTER 2020

www.converter-magazine.info 
length of $5464 \mathrm{~km}$. it spans four geomorphic units from west to east: Qinghai Tibet Plateau, Inner Mongolia Plateau, Loess Plateau and Huang Huai Hai Plain; The drainage area is 795000 square kilometers, accounting for $8 \%$ of the land area [3]; There are nine nationalities in the basin; The GDP of the nine provinces in the Yellow River Basin is 484.2 billion yuan, and the total industrial output value is 601.5 billion yuan, accounting for $5.3 \%$ of the whole country; The total output value of agriculture is 150.9 billion yuan, accounting for $6.1 \%$ of the whole country [4]. The nine provinces along the Yellow River across the East, the middle and the west of China, is an important channel for the economic and technological gradient from the east to the middle and the west of China, and occupies a very important position in the national economic pattern.

\subsection{Concept of sports tourism resources}

Sports tourism resources are an organic combination of tourism resources and sports resources, which attract, encourage people to have sports tourism behavior, create benefits, and can be developed into various objective elements of sports tourism attractions [5-10]. Sports tourism resources can be presented not only in physical form, but also in nonphysical form such as humanities; It includes not only natural resources such as geological landforms and water bodies, but also human resources such as national folk culture and cultural relics, as well as sports resources such as sports events and sports buildings that highlight the characteristics of sports.

\subsection{Data sources}

The data of this study comes from the websites of the Ministry of culture and tourism of the people's Republic of China, the State General Administration of sports and the official websites of the culture and tourism departments of nine provinces and regions in the Yellow River Basin. The data published on the official websites of that year can be taken as the standard, and supplemented with the Tourism Statistical Yearbook and the national statistical yearbook.

\subsection{Research methods}

On the issue of sports tourism resources endowment in the Yellow River Basin, 15 scholars and leaders from the government, colleges and universities, sports industry, sports tourism and tourism culture were interviewed, and the opinions on the selection and weight of sports tourism resources evaluation index were mainly solicited. Through15experts on different types, quality, level of the nine provinces of the Yellow River Basin sports tourism resources endowment score, using MATLAB 7.9toprocess the data, determine the nine provinces of the Yellow River Basin sports tourism resources endowment evaluation index score at all levels.

\section{Evaluation of sports tourism resources in nine provinces of the Yellow River Basin}

\subsection{Selection of evaluation index and determination of weight}

\subsubsection{Selection of evaluation index}

This paper is divided into two stages of index selection and screening to determine the evaluation index of sports tourism resources in nine provinces of the Yellow River Basin. Sports tourism resources cover a wide range, and show the characteristics of cross and permeability with sports industry and tourism industry. It is difficult to comprehensively evaluate the status of sports tourism resources in various regions by formulating quantitative indicators [10]. Therefore, we chose the characteristics of high level, strong attraction and high popularity as the basis of selecting the sports tourism resources of nine provinces in the Yellow River Basin. Firstly, according to the classification standards of "general survey of China's tourism resources", "classification, investigation and evaluation of tourism resources (GB / T18972-2003)", and considering the representativeness of sports tourism resources and the availability of relevant information, sports tourism resources are divided into three categories:

ISSN: 0010-8189 
natural, humanistic and sports tourism resources; Based on the evaluation indexes of Jiang Fugao [10], He Xiaozu [11], Zhang Guanghai [12], combined with the current situation of sports tourism resources in the Yellow River Basin, this paper preliminarily selects individual evaluation indexes; Secondly, in order to avoid the phenomenon that the selected indicators are subject to the subjective influence of researchers, an expert questionnaire on the evaluation index system of sports tourism resources endowment in nine provinces of the Yellow River Basin was designed. 15 experts screened out the indicators and eliminated the indicators that are difficult to operate and highly overlapped, Finally, the evaluation index system of sports tourism resources in nine provinces of the Yellow River Basin is determined, which includes three first level indexes and 27 second level indexes (Table 1).

\subsubsection{Determination of evaluation index weight}

In order to ensure the objectivity of the evaluation results, this study uses entropy to evaluate the endowment of sports tourism resources in nine provinces and regions of the Yellow River Basin. The entropy method mainly determines the index weight according to the information provided by each index. The greater the degree of dispersion of the index, the greater its role in the evaluation [13].This paper uses the entropy method to evaluate the weights of the three first-level indicators. Based on this, the endowment scores of the second-level indicators are obtained, and then the comprehensive scores of sports tourism resources in the nine provinces of the Yellow River Basin are obtained. The main calculation processes are as follows:

(1) Calculate the probability value

Construct a first-level index matrix B, in which the first row represents the scores of natural index experts, the second row represents the scores of humanities index experts, and the third row represents the scores of sports index experts.

$\mathrm{B}=[35,24,6,0,0 ; 5,40,9,2,0 ; 60,4,6,0,0]$

$$
P_{i j}=\frac{B_{i j}}{\sum_{k=1}^{5} B_{i k}}
$$

$P_{i j \tilde{j}}$ represents the probability of expert scoring for class $\mathrm{i}$, and item $\mathrm{j}$.

(2) Determine entropy

$$
E_{\mathrm{i}}=-\ln (n)^{-1} \sum_{j}^{5} P_{\mathrm{ij}} \ln P_{\mathrm{ij}}
$$

$\mathrm{i}=1,2,3$, representing the three class I indicators, $E_{\tilde{i}}$ represents the entropy of each type of indicator

\subsection{Evaluation of sports tourism resource endowment in nine provinces of the Yellow River Basin}

3.2.1 The secondary index endowment value of sports tourism resources in nine provinces of the Yellow River Basin

Firstly, refer to the "China Tourism Resources Census Standards" and "Tourism Resources Classification, Investigation and Evaluation (GB/T 18972-2003)" to set scoring standards for sports tourism resources evaluation. Assign the partition interval to $[1,20]$. The more important the index, the higher the score. Secondly, 15 experts evaluated and assigned points for different categories and different levels of sports tourism resources, and then used the entropy method to obtain the weights of 3 first-level indicators. Finally, the indicators are combined with experts' evaluation to assign the second-level indicators. Finally, combined with the expert's assignment of secondary indicators, the used of Matlab7.9 data statistics, and obtain the endowment values of the second-level indicators (Table 1). The specific calculation process is as follows:

$$
F=\mathrm{X}^{*}{ }^{*} \mathrm{~W}
$$

ISSN: 0010-8189

(c) CONVERTER 2020

www.converter-magazine.info 
Volume 2021, No. 4

The $\mathrm{F}$ is the secondary indicator endowment value, $\mathrm{X}$ is the score of 15 experts, $\mathrm{W}$ is the weight of the first-level index corresponding to each second-level index. Based on the above index data, the secondary index endowment scores and rankings of sports tourism resources in nine provinces along the Yellow River Basin can be calculated (Table 1).

Table 1 The weights of primary indexes and endowment values of secondary indexes of sports tourism resources in nine provinces of the Yellow River Basin

\begin{tabular}{|c|c|c|c|c|}
\hline $\begin{array}{c}\text { Level } \\
\text { indicators } \\
\text { (proportion } \\
\text { ) } \\
\end{array}$ & Secondary indicators & $\begin{array}{l}\text { Expert } \\
\text { ratings }\end{array}$ & $\begin{array}{c}\text { Endowment } \\
\text { value }\end{array}$ & rank \\
\hline \multirow{10}{*}{$\begin{array}{l}\text { Nature }(0.11 \\
21)\end{array}$} & National 4AScenic Area & 176 & 1.3153 & 26 \\
\hline & National 5A Scenic Area & 221 & 1.6516 & 18 \\
\hline & National Geological Park & 192 & 1.4349 & 24 \\
\hline & National Water Scenic Area & 171 & 1.2779 & 27 \\
\hline & $\begin{array}{c}\text { National Marine Nature } \\
\text { Reserve }\end{array}$ & 188 & 1.4050 & 25 \\
\hline & National Scenic Areas & 218 & 1.6292 & 19 \\
\hline & National Natural Reserve & 209 & 1.5619 & 21 \\
\hline & National Holiday Resort & 232 & 1.7338 & 17 \\
\hline & National Forest Park & 207 & 1.547 & 22 \\
\hline & National Wetland Park & 202 & 1.5096 & 23 \\
\hline \multirow{9}{*}{$\begin{array}{l}\text { Humanities } \\
(0.1864)\end{array}$} & $\begin{array}{c}\text { National industrial tourism } \\
\text { demonstration site }\end{array}$ & 131 & 1.6279 & 20 \\
\hline & World Heritage List & 190 & 2.3611 & 11 \\
\hline & $\begin{array}{c}\text { National recreational } \\
\text { fishery park }\end{array}$ & 166 & 2.0628 & 13 \\
\hline & $\begin{array}{c}\text { National Excellent Tourist } \\
\text { City }\end{array}$ & 216 & 2.6842 & 9 \\
\hline & $\begin{array}{c}\text { National historical and } \\
\text { cultural city }\end{array}$ & 214 & 2.6593 & 10 \\
\hline & $\begin{array}{c}\text { National historical and } \\
\text { cultural town }\end{array}$ & 184 & 2.2865 & 12 \\
\hline & $\begin{array}{c}\text { National historical and } \\
\text { cultural village }\end{array}$ & 166 & 2.0628 & 13 \\
\hline & $\begin{array}{c}\text { National Leisure } \\
\text { Agriculture and Tourism } \\
\text { Demonstration Unit } \\
\text { (Demonstration point) }\end{array}$ & 166 & 2.0628 & 13 \\
\hline & $\begin{array}{c}\text { National Leisure } \\
\text { Agriculture and Tourism } \\
\text { Demonstration Unit } \\
\text { (Demonstration county) }\end{array}$ & 147 & 1.8267 & 16 \\
\hline \multirow{4}{*}{$\begin{array}{l}\text { Sports } \\
(0.7016)\end{array}$} & Boutique sports tour routes & 264 & 12.3482 & 2 \\
\hline & $\begin{array}{c}\text { National Sports Tourism } \\
\text { Demonstration Base }\end{array}$ & 257 & 12.0207 & 3 \\
\hline & Golf Course & 202 & 9.4482 & 8 \\
\hline & $\begin{array}{l}\text { National sports industry } \\
\text { demonstration base }\end{array}$ & 231 & 10.8046 & 5 \\
\hline
\end{tabular}

ISSN: 0010-8189

(c) CONVERTER 2020 
CONVERTER MAGAZINE

Volume 2021, No. 4

\begin{tabular}{|c|c|c|c|c|}
\hline & $\begin{array}{c}\text { National Sports Industry } \\
\text { Demonstration Unit }\end{array}$ & 215 & 10.0563 & 6 \\
\cline { 2 - 5 } & $\begin{array}{c}\text { National Sports Industry } \\
\text { Demonstration Project }\end{array}$ & 211 & 9.8692 & 7 \\
\cline { 2 - 5 } & $\begin{array}{c}\text { National Mountaineering } \\
\text { Trail }\end{array}$ & 248 & 11.5998 & 1 \\
\cline { 2 - 5 } & $\begin{array}{c}\text { National Sports Tourism } \\
\text { Boutique Event }\end{array}$ & 268 & 12.5353 & 1 \\
\hline
\end{tabular}

From Table 1, we can find that the ranking of secondary sports tourism resources in sports category is higher than the index of humanities and natural sports tourism resources, and its endowment contributes the most, which is much higher than the important value of the other two indexes. In terms of the endowment value of the secondary indexes, the expert score and endowment score of the 8 kinds of sports tourism resources are higher than the other two kinds of sports tourism resources. The score of sports tourism resources accounts for about 5 times of the score of humanistic sports tourism resources, and about 10 times of the score of natural sports tourism resources, with significant differences.

3.2.2 The comprehensive endowment value of sports tourism resources in the nine provinces of the Yellow River Basin

Firstly, we can obtain the statistics of nine provinces and regions of the single sports tourism resources type and quantity (Table 2). Secondly, combined with the endowment value of the second-level index, the judgment matrix is constructed for the three kinds of first-level index, and then the endowment value of the three-level index in the nine provinces and regions is obtained. Finally, the comprehensive endowment value of sports tourism resources in nine provinces is obtained (Table 3 ). The calculation process is as follows:

1. Calculate the endowment value of natural sports tourism resources

(1) Build judgment matrix A1:

$$
A_{l}=\left[\begin{array}{ccccccccc}
19 & 245 & 90 & 17 & 109 & 95 & 95 & 131 & 212 \\
\mathbf{3} & 12 & \mathbf{4} & \mathbf{4} & \mathbf{5} & \mathbf{9} & \mathbf{8} & 13 & 11 \\
7 & 18 & 11 & \mathbf{1} & 12 & 10 & 10 & 15 & 13 \\
16 & 42 & 29 & 12 & 30 & 42 & 20 & 54 & 102 \\
\mathbf{0} & \mathbf{0} & \mathbf{0} & \mathbf{0} & \mathbf{0} & \mathbf{0} & \mathbf{0} & \mathbf{0} & 2 \\
\mathbf{1} & 15 & \mathbf{4} & 2 & 2 & \mathbf{5} & \mathbf{6} & 10 & \mathbf{6} \\
\mathbf{7} & 32 & 21 & \mathbf{9} & 29 & 27 & 7 & 13 & 7 \\
\mathbf{0} & 2 & \mathbf{0} & \mathbf{0} & \mathbf{0} & \mathbf{0} & \mathbf{0} & \mathbf{1} & \mathbf{3} \\
\mathbf{7} & 38 & 23 & \mathbf{4} & 35 & 35 & 22 & 31 & 49 \\
12 & 13 & 49 & 38 & 17 & 31 & 65
\end{array}\right]
$$

(2) Calculate the endowment value vector $\mathrm{W} 1$ of natural sports tourism resources index $W_{l}=[1.315,1.652,1.435,1.278,1.405,1.629,1.562,1.734,1.547,1.510]$

(3) Calculate the endowment value $\mathrm{S} 1$ of natural sports tourism resources in nine provinces $S_{l}=A_{l}{ }^{*} W_{l}(5)$

$S_{l}=[112.510,602.019,270.839,88.865,383.850,369.666,258.479,417.390$, 648.658]

Thereinto, $\mathrm{S} 1$ is a nine-dimensional vector, each value corresponds to the natural sports tourism resource endowment value of different provinces and regions.

2. Calculate the value of humanistic endowments

(1) Build judgment matrix A2:

ISSN: 0010-8189

(C) CONVERTER 2020

www.converter-magazine.info 


$$
A_{2}=\left[\begin{array}{ccccccccc}
0 & 3 & 3 & 1 & 2 & 0 & 5 & 10 & 6 \\
2 & 5 & 3 & 1 & 2 & 3 & 4 & 6 & 4 \\
1 & 2 & 3 & 0 & 3 & 3 & 4 & 5 & 5 \\
2 & 21 & 9 & 1 & 11 & 6 & 5 & 27 & 36 \\
1 & 8 & 4 & 1 & 1 & 6 & 6 & 8 & 10 \\
1 & 31 & 8 & 0 & 5 & 7 & 15 & 10 & 4 \\
5 & 6 & 5 & 1 & 2 & 3 & 96 & 9 & 11 \\
4 & 5 & 5 & 3 & 4 & 5 & 4 & 5 & 5 \\
1 & 3 & 2 & 1 & 1 & 3 & 2 & 2 & 3
\end{array}\right]
$$

(2) Calculate the endowment value vector W2 of the human sports tourism resource index $W_{2}=[1.628,2.361,2.063,2.684,2.659,2.287,2.063,2.063,1.827]$

(3) Calculate the endowment value $\mathrm{S} 2$ of humanistic sports tourism resources in nine provinces and regions $S_{2}=[37.491,197.51,95.524,19.41,71.988,83.321,299.44,189.91,200.38]$

3. Calculate the endowment value of sports tourism resources

(1) Build judgment matrix A3:

$$
A_{3}=\left[\begin{array}{ccccccccc}
1 & 1 & 0 & 0 & 1 & 0 & 0 & 1 & 0 \\
1 & 1 & 1 & 1 & 1 & 1 & 1 & 1 & 2 \\
1 & 9 & 1 & 1 & 7 & 5 & 4 & 4 & 35 \\
1 & 1 & 3 & 0 & 1 & 1 & 0 & 2 & 3 \\
1 & 0 & 3 & 1 & 2 & 0 & 0 & 1 & 4 \\
1 & 2 & 1 & 0 & 4 & 1 & 1 & 1 & 4 \\
0 & 3 & 1 & 0 & 1 & 0 & 2 & 5 & 4 \\
1 & 1 & 1 & 1 & 1 & 1 & 1 & 1 & 1
\end{array}\right]
$$

(2) Calculate the endowment value vector $\mathrm{W} 3$ of sports sports tourism resources index $W_{3}=[12.348,12.021,9.448,10.805,10.056,9.869,11.600,12.535]$

(3) Calculate the endowment value S3 of sports tourism resources in nine provinces and regions $S_{3}=[77.083,187.28,118.06,44.061,185.04,92.471,95.418,174.23,525.78]$

\begin{tabular}{|c|c|c|c|c|c|c|c|c|c|c|}
\hline Type & Sports tourism resources list & $\begin{array}{l}\text { Qin } \\
\text { ghai }\end{array}$ & $\begin{array}{l}\text { Sich } \\
\text { uan }\end{array}$ & $\begin{array}{c}\mathrm{Ga} \\
\mathrm{ns} \\
\mathrm{u}\end{array}$ & $\begin{array}{c}\text { Ning } \\
\text { xia }\end{array}$ & $\begin{array}{c}\text { Inner } \\
\text { Mongol } \\
\text { ia }\end{array}$ & $\begin{array}{l}\text { Shaa } \\
\text { nxi }\end{array}$ & $\begin{array}{c}\text { Shan } \\
\text { xi }\end{array}$ & $\begin{array}{c}\text { Hena } \\
\mathrm{n}\end{array}$ & $\begin{array}{l}\text { Shan } \\
\text { dong }\end{array}$ \\
\hline \multirow{9}{*}{ Z্: } & $\begin{array}{c}\text { National } \\
\text { 4A Scenic Area }\end{array}$ & 19 & 245 & 90 & 17 & 109 & 95 & 95 & 131 & 212 \\
\hline & National 5A Scenic Area & 3 & 12 & 4 & 4 & 5 & 9 & 8 & 13 & 11 \\
\hline & National Geological Park & 7 & 18 & 11 & 1 & 12 & 10 & 10 & 15 & 13 \\
\hline & National Water Scenic Area & 16 & 42 & 29 & 12 & 30 & 42 & 20 & 54 & 102 \\
\hline & National Marine Nature Reserve & 0 & 0 & 0 & 0 & 0 & 0 & 0 & 0 & 2 \\
\hline & National Scenic Areas & 1 & 15 & 4 & 2 & 2 & 5 & 6 & 10 & 6 \\
\hline & National Natural Reserve & 7 & 32 & 21 & 9 & 29 & 27 & 7 & 13 & 7 \\
\hline & National Holiday Resort & 0 & 2 & 0 & 0 & 0 & 0 & 0 & 1 & 3 \\
\hline & National Forest Park & 7 & 38 & 23 & 4 & 35 & 35 & 22 & 31 & 49 \\
\hline \multirow{3}{*}{$\& \frac{E}{E}$} & National Wetland Park & 19 & 29 & 12 & 13 & 49 & 38 & 17 & 31 & 65 \\
\hline & $\begin{array}{l}\text { National industrial tourism } \\
\text { demonstration site }\end{array}$ & 0 & 3 & 3 & 1 & 2 & 0 & 5 & 10 & 6 \\
\hline & World Heritage List & 2 & 5 & 3 & 1 & 2 & 3 & 4 & 6 & 4 \\
\hline
\end{tabular}

Table 2 Number of sports tourism resources in nine provinces

ISSN: 0010-8189

(C) CONVERTER 2020

www.converter-magazine.info 


\begin{tabular}{|c|c|c|c|c|c|c|c|c|c|}
\hline National recreational fishery park & 1 & 2 & 3 & 0 & 3 & 3 & 4 & 5 & 5 \\
\hline National Excellent Tourist City & 2 & 21 & 9 & 1 & 11 & 6 & 5 & 27 & 36 \\
\hline $\begin{array}{l}\text { National historical and cultural city } \\
\text { National historical and cultural }\end{array}$ & 1 & 8 & 4 & 1 & 1 & 6 & 6 & 8 & 10 \\
\hline town & 1 & 31 & 8 & 0 & 5 & 7 & 15 & 10 & 4 \\
\hline $\begin{array}{l}\text { National historical and cultural } \\
\text { village }\end{array}$ & 5 & 6 & 5 & 1 & 2 & 3 & 96 & 9 & 11 \\
\hline $\begin{array}{l}\text { National Leisure Agriculture and } \\
\text { Tourism Demonstration Unit }\end{array}$ & & & & & & & & & \\
\hline ( Demonstration point ) & 4 & 5 & 5 & 3 & 4 & 5 & 4 & 5 & 5 \\
\hline $\begin{array}{l}\text { National Leisure Agriculture and } \\
\text { Tourism Demonstration Unit }\end{array}$ & & & & & & & & & \\
\hline ( Demonstration county ) & 1 & 3 & 2 & 1 & 1 & 3 & 2 & 2 & 3 \\
\hline Boutique sports tour routes & 1 & 1 & 0 & 0 & 1 & 0 & 0 & 1 & 0 \\
\hline National Sports Tourism & 1 & 1 & 1 & 1 & 1 & 1 & 1 & 1 & 2 \\
\hline Golf Course & 1 & 9 & 1 & 1 & 7 & 5 & 4 & 4 & 35 \\
\hline National sports industry & & & & & & & & & \\
\hline demonstration base & 1 & 1 & 3 & 0 & 1 & 1 & 0 & 2 & 3 \\
\hline National Sports Industry & & & & & & & & & \\
\hline $\begin{array}{l}\text { Demonstration Unit } \\
\text { National Snorts Industry }\end{array}$ & 1 & 0 & 3 & 1 & 2 & 0 & 0 & 1 & 4 \\
\hline Demonstration Project & 1 & 2 & 1 & 0 & 4 & 1 & 1 & 1 & 4 \\
\hline National Mountaineering Trail & 0 & 3 & 1 & 0 & 1 & 0 & 2 & 5 & 4 \\
\hline National Sports Tourism Boutique & & & & & & & & & \\
\hline & 1 & 1 & 1 & 1 & 1 & 1 & 1 & 1 & 1 \\
\hline
\end{tabular}

Table 3 The endowment of sports tourism resources in nine provinces

\begin{tabular}{cccccc}
\hline Province & Nature & Humanities & Sports & Comprehensi \\
ve score & rank \\
\hline Qinghai & 112.5101 & 37.4911 & 77.0825 & 227.1 & 8 \\
Sichuan & 602.0185 & 197.5098 & 187.2804 & 986.8 & 2 \\
Gansu & 270.8393 & 95.5238 & 118.0559 & 484.4 & 7 \\
Ningxia & 88.8645 & 19.4104 & 44.0605 & 152.3 & 9 \\
Inner Mongolia & 383.8504 & 71.9879 & 185.0354 & 640.9 & 5 \\
Shaanxi & 369.6658 & 83.3207 & 92.4708 & 545.5 & 6 \\
Shanxi & 258.479 & 299.4428 & 95.4176 & 653.3 & 4 \\
Henan & 417.3903 & 189.905 & 174.2307 & 781.5 & 3 \\
Shandong & 648.6576 & 200.3809 & 525.7787 & 1374.8 & 1 \\
\hline
\end{tabular}

Table 4 Endowment Index of Sports Tourism Resources in Nine provinces of the Yellow River Basin

\begin{tabular}{cccccc}
\hline $\begin{array}{c}\text { Provi } \\
\text { nces }\end{array}$ & $\begin{array}{c}\text { Endowment index of } \\
\text { natural sportstourism } \\
\text { resources }\end{array}$ & $\begin{array}{c}\text { Endowment Index of } \\
\text { Humanistic Sports } \\
\text { Tourism Resources }\end{array}$ & $\begin{array}{c}\text { Endowment Index } \\
\text { of Sports Tourism } \\
\text { Resources }\end{array}$ & $\begin{array}{c}\text { Comprehensive } \\
\text { endowment index of } \\
\text { sports tourism resources }\end{array}$ \\
\hline $\begin{array}{c}\text { Qingha } \\
\text { i }\end{array}$ & $\begin{array}{c}\text { re } \\
\text { Ra }\end{array}$ & 0.0357 & 0.0314 & 0.0514 & 0.0388 \\
nki & 8 & 8 & 8 & 8
\end{tabular}

ISSN: 0010-8189

(c) CONVERTER 2020

www.converter-magazine.info 


\begin{tabular}{|c|c|c|c|c|c|}
\hline & $\begin{array}{c}\text { sco } \\
\text { re } \\
\mathrm{Ra}\end{array}$ & 0.191 & 0.1653 & 0.1249 & 0.1688 \\
\hline Sichua & nki & & & & \\
\hline \multirow[t]{2}{*}{$\mathrm{n}$} & $\begin{array}{l}\text { ng } \\
\text { sco }\end{array}$ & 2 & 3 & 2 & 2 \\
\hline & $\begin{array}{l}\text { re } \\
\text { Ra } \\
\text { nki }\end{array}$ & 0.0859 & 0.0799 & 0.0787 & 0.0829 \\
\hline \multirow[t]{2}{*}{ Gansu } & $\begin{array}{l}\text { ng } \\
\text { sco }\end{array}$ & 6 & 5 & 5 & 7 \\
\hline & $\begin{array}{l}\mathrm{re} \\
\mathrm{Ra}\end{array}$ & 0.0282 & 0.0162 & 0.0294 & 0.026 \\
\hline \multirow[t]{2}{*}{$\mathrm{a}$} & $\begin{array}{c}\text { nki } \\
\text { ng }\end{array}$ & 9 & 9 & 9 & 9 \\
\hline & $\begin{array}{c}\text { sco } \\
\text { re }\end{array}$ & 0.1218 & 0.0602 & 0.1234 & \\
\hline $\begin{array}{c}\text { Inner } \\
\text { Mongol }\end{array}$ & $\begin{array}{l}\text { Ra } \\
\text { nki }\end{array}$ & & & & \\
\hline \multirow[t]{2}{*}{ ia } & $\begin{array}{l}\text { ng } \\
\text { sco }\end{array}$ & 4 & 7 & 3 & 5 \\
\hline & $\begin{array}{l}\text { re } \\
\text { Ra } \\
\text { nki }\end{array}$ & 0.1173 & 0.0697 & 0.0617 & 0.0933 \\
\hline \multirow{2}{*}{$\begin{array}{c}\text { Shaanx } \\
\text { i }\end{array}$} & $\begin{array}{l}\text { ng } \\
\text { sco }\end{array}$ & 5 & 6 & 7 & 6 \\
\hline & $\begin{array}{l}\mathrm{re} \\
\mathrm{Ra} \\
\mathrm{nki}\end{array}$ & 0.082 & 0.2506 & 0.0636 & 0.1117 \\
\hline \multirow[t]{2}{*}{ Shanxi } & $\begin{array}{l}\text { ng } \\
\text { sco }\end{array}$ & 7 & 1 & 6 & 4 \\
\hline & $\begin{array}{l}\text { re } \\
\text { Ra } \\
\text { nki }\end{array}$ & 0.1324 & 0.1589 & 0.1162 & 0.1337 \\
\hline \multirow[t]{2}{*}{ Henan } & $\begin{array}{l}\text { ng } \\
\text { sco }\end{array}$ & 3 & 4 & 4 & 3 \\
\hline & $\begin{array}{l}\mathrm{re} \\
\mathrm{Ra}\end{array}$ & 0.2058 & 0.1677 & 0.3507 & 0.2351 \\
\hline $\begin{array}{c}\text { Shando } \\
\text { ng }\end{array}$ & $\begin{array}{c}\text { nki } \\
\text { ng }\end{array}$ & 1 & 2 & 1 & 1 \\
\hline
\end{tabular}

3.2.3 Evaluation and Analysis of Sports Tourism Resources Endowment in Nine Provinces of the Yellow River Basin

Table 2 shows that there are many kinds of sports tourism resources in the Yellow River Basin, with uneven spatial distribution and significant differences in resource endowment ratio. Table 3 shows that there is a significant difference in the endowment value of sports tourism resources among the nine provinces and regions in the Yellow River Basin, and the regional imbalance is obvious. Shandong ranks first with a score of 1374.8, accounting for $23.51 \%$ of the total sports tourism resources in the nine provinces and regions; All kinds of sports tourism resources are abundant; Sichuan Province ranks second, followed by Shanxi, Inner Mongolia and Shaanxi, while Gansu, Qinghai and Ningxia have relatively few sports tourism resources and belong to low resource endowment areas. The score and ranking analysis results of secondary indicators are as follows:

(1)The spatial distribution of 10 natural sports tourism resources is uneven. Shandong has the largest endowment ISSN: 0010-8189

www.converter-magazine.info 
value, followed by Sichuan, which accounts for about $40 \%$ of the total natural sports tourism resources in nine provinces of the Yellow River Basin. In contrast, Qinghai and Ningxia rank eighth and ninth in terms of endowment value, accounting for only $6.4 \%$ of the total natural sports tourism resources in this region.

(2)There are significant differences in the spatial distribution of 9 kinds of humanistic sports tourism resources. Shanxi, Shandong, Sichuan and Henan provinces are rich in human sports tourism resources, accounting for $74 \%$ of the total. Shanxi alone accounts for more than $1 / 4$ of the total human sports tourism resources in the nine provinces and regions of the Yellow River basin. Ningxia, Qinghai, Inner Mongolia, etc. are located in the remote areas of northwest China, and their humanistic advantages are insufficient and need to be further opened up.

(3)In terms of endowment index, Shandong, Sichuan and Henan rank the top three in the endowment index of natural sports tourism resources; Shanxi, Shandong, Sichuan and Inner Mongolia rank the top three in the endowment index of human sports tourism resources.

From the comprehensive endowment index, Table 4 shows that Shandong tops the list, followed by Sichuan and Henan, forming a high endowment area of sports tourism resources. Among the sports industry competitiveness of 31 provinces and cities in China, Shandong ranks third in the country, and Henan and Sichuan rank ninth and tenth respectively; Inner Mongolia, Shaanxi and Shanxi ranked 15th, 18th and 20th respectively. Ningxia, Gansu and Qinghai ranked 27th, 28th and 30th respectively. Shanxi, Inner Mongolia and Shaanxi have formed resource endowment areas with their profound cultural accumulation and abundant natural resources. Gansu, Qinghai and Ningxia are located inland, and sports tourism resources are scarce, which belong to low resource endowment areas.

\section{Conclusions and Suggestions}

(1) The regional differentiation is the prominent feature of the sports tourism resources endowment in the nine provinces of the Yellow River Basin, showing a spatial distribution pattern of rich in the southeast, poor in the northwest and moderate in the north central.

(2) Heterogeneity is the concentrated embodiment of the abundance of sports tourism resources in nine provinces and regions of the Yellow River Basin, which is manifested in three types of regional difference grade sequence: resource rich type, medium rich type and poor type. Suggestions are as follows: according to the differences of sports tourism resources in nine provinces and autonomous regions of the Yellow River Basin, accurately positioning the development scale of sports tourism resources, deeply innovating the product system of sports tourism, and scientifically deciding the integration path of sports tourism resources; designing, planning, developing and publicizing sports tourism resources in a targeted way, so as to continuously improve the benefits of sports tourism resources in the Yellow River Basin and effectively promote the coordinated development of sports tourism industry in nine provinces and regions of the Yellow River Basin.

\section{Reference}

[1] Q. Yang, 20 Years of Research on Chinese Sports Tourism: Review and Prospect, China Sports Science and Technology, vol. 47, no. 05, pp. 90-100+115, 2011.

[2] National strategy: the national fitness, body brigade fusion, https://www.sohu.com/a/427275410_505583, 2020.

[3] Basins range and its historical change, http://www.yrcc.gov.cn/hhyl/hhgk/hd/lyfw/201108/t20110814_103452.html, 2011.

[4] The Yellow River to assume what the population of the country, https://zhidao.baidu.com/question/1704890561944566460.html, 2016.

ISSN: 0010-8189

(c) CONVERTER 2020

www.converter-magazine.info 
[5] China National Tourism Administration. Classification, Investigation and Evaluation of Tourism Resources (GB/T18972-2003), Beijing: Standards Press of China, 2003.

[6] H.Y. Huang, L. Zhang, Sports Tourism, Beijing: Higher Education Press, 2016.

[7] F.L. Deng, "Study on Evaluation Index System of Sports Tourism Humanistic Resource in China and Evaluation Scale, Journal of Beijing Sport University, vol. 37, no. 1, pp. 58-63, 2014.

[8] S.M. Yu, "Research on the Development of Sports Tourism Resources in Well-off Society," Sports Science, vol. 27, no. 5, pp. 23-35, 2007.

[9] Z.L. Shu, G .X. Xia, Y. Shi, "Research on Comprehensive Development of Sports Tourism Resources in Hubei Province, Journal of Physical Education, Culture and Chemistry, no. 4, pp. 74-77, 2010.

[10] F.G. Jiang, L. Cao, J.H. Sun, P.F. Tai, Z.J. Li, "The Assessment of the Endowment, Abundance and Performance Evaluation of Sports Tourism Resources of the Coastal Regions in China," Journal of Tianjin Institute of Physical Education, vol. 31, no. 04, pp.277-282, 2016.

[11] X.Z. He, Evaluation of tourism resources and empirical analysis of tourism destination based on the research of regional system structure, Lanzhou: Lanzhou University, pp: 90-94, 2007.

[12] G.H. Zhang, J. Wang, A Study on the Evaluation of Tourism Resources Competitiveness and the Development Model in China, Journal of Ocean University of China: Social Sciences Edition, no. 2, pp. 43-50, 2013.

[13] M.X. Hu, X.D. Yuan, Evaluation of Comprehensive Strength of Marine Industry in China's Coastal Areas Based on Entropy Method, Marine Development and Management, vol. 38, no. 03, pp. 84-90, 2014.

[14] B.B. Luo, The research of cultural tourism resources development in Hubei Province Wuling mountainous area, Wuhan: Central China Normal University, 2012. 